\title{
AMELIORATIVE POTENTIAL OF STEM BROMELAIN ON LEAD-INDUCED TOXICITY IN WISTAR RATS
}

\author{
Wedad Refaiea Al-Otaibi, Promy Virk* and Mai Elobeid \\ Department of Zoology, King Saud University, P.O. Box 22452, \\ Riyadh-11495, Saudi Arabia
}

(Received: October 28, 2014; accepted: December 11, 2014)

\begin{abstract}
The present study investigates the protective efficacy of stem bromelain against lead-induced toxicity in male Wistar rats. There were six experimental groups; Group I was negative control, Group II was administered only $20 \mathrm{mg} / \mathrm{kg}$ of stem bromelain. Group III and V were orally exposed to $30 \mathrm{mg} / \mathrm{kg} / \mathrm{day}$ and $60 \mathrm{mg} / \mathrm{kg} /$ day of lead acetate, respectively. Group IV and Group VI were exposed to both low and high dose of lead acetate, respectively, and treated with $20 \mathrm{mg} / \mathrm{kg}$ stem bromelain. The experimental period was 21 days. The end points evaluated were, lead accumulation in kidney, liver and spleen, alanine aminotransferase (ALT) and aspartate aminotransferase (AST) activity, serum malonaldehyde (MDA) cholesterol and triglycerides levels. Co-administration of stem bromelain with lead markedly reduced the lead accumulation in the kidney and spleen. The treatment of stem bromelain also reduced the serum MDA levels in the group exposed to lower dose of lead and serum triglyceride level in the group exposed to higher dose of lead. The lead-induced modulated levels of serum ALT and AST were also alleviated by bromelain treatment. Our key findings suggest a chelating potential of stem bromelain for combating lead toxicity and oxidative stress. Bromelain represents a novel approach to the treatment of metal toxicity and metabolic disorders with a limited therapeutic window.
\end{abstract}

Keywords: Lead acetate - bromelain - oxidative stress - hepatic damage

\section{INTRODUCTION}

Lead $(\mathrm{Pb})$ is a toxic heavy metal and the most important exposure route is through the ingestion of $\mathrm{Pb}$-polluted food or soil [6]. $\mathrm{Pb}$ accumulates in many body organs, primarily in the liver, kidneys and bone thus causing cellular damage [24]. Recently, it has been suggested that certain physiological disorders attributed to this heavy metal are directly or indirectly related to the generation of reactive oxygen species (ROS) that leads to a condition termed as oxidative stress [2, 14, 20]. Plant extracts and phytoconstituents have been found to be effective as radical scavengers and inhibitors of lipid peroxidation [10]. It has been hypothesized that usage of an antioxidant agent in the presence of a chelator would increase the efficacy of intoxication treatment with lead [12]. Currently there has been an increased interest globally to identify

*Corresponding author; e-mail address: virkg@hotmail.com 
compounds from plant sources which are pharmacologically potent and have low or no side effects for use in protective medicine and the food industry.

The medicinal qualities of pineapple plant, Ananas comosus have been recognized in several native cultures [11] and are attributed to bromelain (EC 3.4.22.32), which is a crude extract from pineapple stem or fruit. Bromelain contains, among other compounds, various closely related thiol endopeptidases, exhibiting various fibrinolytic, antithrombotic, and anti-inflammatory activities in vitro and in vivo. Bromelain concentration is high in pineapple stem, thus necessitating its extraction, as the stem is a waste byproduct and thus inexpensive [22]. Bromelain can be absorbed in human intestines without degradation and without losing its biological activity [7]. Bromelain has a wide range of therapeutic benefits, but the mode of its action is not well understood. An extensive review by Pavan et al. [18] suggest that bromelain can be an effective potential health supplement to prevent cancer, diabetes, and various cardiovascular diseases in the near future.

With the present premise, this study was designed to assess the ameliorative effect of stem bromelain on the $\mathrm{Pb}$ induced toxicity.

\section{MATERIALS AND METHODS}

\section{Chemicals}

All chemicals were obtained commercially and were of analytical grade. Lead acetate (trihydrate) $\left(\mathrm{Pb}\left(\mathrm{C}_{2} \mathrm{H}_{3} \mathrm{O}_{2}\right)_{2} \cdot 3 \mathrm{H}_{2} \mathrm{O}\right.$ was procured from LOBA Chemie (India). Stem bromelain extract as capsules $\left(2400 \mathrm{GDU} / \mathrm{g}\right.$ ), was procured from $\mathrm{iHerb}{ }^{\circledR}$ (United States). Commercial kits for the estimation of serum cholesterol and triglycerides were procured from Roche (USA). Commercial ELISA kits used for the estimation of enzyme activity (alanine aminotransferase, ALT and aspartate aminotransferase, AST) were procured from CUSABIO Life Sciences (China).

\section{Experimental design}

Forty-five male Wistar rats weighing 150-200 g were procured from the Animal House facility at King Saud University, Riyadh in the month of April, 2013. All animal treatments were performed in accordance with the standards set forth in the Guidelines for the Care and Use of Experimental Animals by the Committee for the Purpose of Control and Supervision of Experiments on Animals (CPCSEA) and the National Institute of Health (NIH) (http://icmr.nic.in/bioethics/final_cpcsea.pdf). The study protocol was approved by the Animal Ethics Committee of the Zoology Department, College of Science, King Saud University. The animals were acclimated to the laboratory conditions for two weeks prior to the experimental period. Thereafter, the animals were divided into six groups each comprising seven rats. Rats were exposed for three weeks to the following treatments: 
Group I - negative control (administered only normal saline)

Group II - administered only $\mathrm{Br} 20 \mathrm{mg} / \mathrm{kg}$

Group III - exposed to only PbAc (lead acetate) $30 \mathrm{mg} / \mathrm{kg}$ (positive control)

Group IV - exposed to only PbAc $30 \mathrm{mg} / \mathrm{kg}$ + treated with $\mathrm{Br} 20 \mathrm{mg} / \mathrm{kg}$

Group V - exposed to only $\mathrm{PbAc} 60 \mathrm{mg} / \mathrm{kg}$ (positive control)

Group VI - exposed to PbAc $60 \mathrm{mg} / \mathrm{kg}$ + treated with $\mathrm{Br} 20 \mathrm{mg} / \mathrm{kg}$

Bromelain capsules were crushed and ground and administered in normal saline. The doses were given daily at $8 \mathrm{am}$. During the experimental period the rats were fed with the laboratory chow. The body weight was recorded on weekly intervals during the experimental period. After the experimental period was over blood was drawn by the orbital sinus venipuncture from the rats of each experimental group and serum was prepared. The serum was prepared by drawing the blood into red stoppered tubes and left at room temperature for clotting followed by centrifugation at $3500 \mathrm{rpm}$ for 15-20 min.The animals were sacrificed and dissected to excise the liver, kidney and spleen. The tissues and serum was stored at $-80{ }^{\circ} \mathrm{C}$ till further analysis. The serum was used for the analysis of lipid profile, MDA level and enzymes.

\section{Determination of lead concentration}

Samples of kidney, liver, and spleen $(0.5 \mathrm{~g}$ each) were wet digested with $3.5 \mathrm{ml}$ of $\mathrm{HNO}_{3}(65 \%)$ and $0.5 \mathrm{~mL}$ of $\mathrm{H}_{2} \mathrm{O}_{2}(30 \%)$ in a microwave digestor (Milestone, Italy). The concentration of lead in digested tissue samples was analyzed in an atomic absorption spectrophotometer (220 FS Varian, Australia) at wavelength of $228.8 \mathrm{~nm}$ (detection limit $0.0020 \mu \mathrm{g} / \mathrm{ml}$ ) with $4.0 \mathrm{~mA}$ current. The final concentrations were expressed as $\mu \mathrm{g} / \mathrm{g}$.

\section{Biochemical analysis}

\section{Lipid profile}

Total cholesterol and triglycerides levels in the serum samples were determined using commercially available Reflotron test strips.

\section{Determination of serum MDA level}

MDA levels in serum were determined using the Alliance Waters High performance Liquid Chromatography (HPLC) 2695 system and a multi fluorescence detector, Model 2475. This system was operated by a Dell Optiplex GX1 computer and Empower software. The reversed-phase analytical HPLC column was a ODS Hypersil from Thermo Scientific $(4.6 \mathrm{~mm} \times 25.0 \mathrm{~cm} \times 5 \mu \mathrm{m})$. A guard column, Waters 
Symmetry TM C18 $(4.6 \mathrm{~mm} \times 2 \mathrm{~cm}, 5 \mu \mathrm{m}$ particle size $)$ with the same packing materials was placed in front of the analytical column for protection. The elution was carried out at a flow rate of $1.0 \mathrm{~mL} / \mathrm{min}$. The column effluent was quantified at an excitation and emission wavelengths of 515 and $553 \mathrm{~nm}$, respectively. Run time per sample was $4.0 \mathrm{~min}$. Aliquots of $25 \mu \mathrm{L}$ of serum were mixed thoroughly with $1 \mathrm{~mL}$ of Thiobarbituric acid (TBA) reagent and $10 \mu \mathrm{L}$ of $5 \%$ Butylated hydroxytoluene (BHT) solution, vortexed for 2 minutes and then heated for $60 \mathrm{~min}$ in a water bath at $95^{\circ} \mathrm{C}$. Hereafter, the sample was cooled for 20 minutes and then centrifuged at $4,000 \mathrm{rpm}$ for $15 \mathrm{~min}$. Supernatants were transferred to a glass vial, and injected a $5 \mu \mathrm{L}$ aliquot onto the column. The stock solution of 1,1,3,3 tetraethoxypropane (TEP) $(10 \mu \mathrm{mol} / \mathrm{mL})$ was prepared by dissolving $240 \mu \mathrm{L}$ of $4.176 \mathrm{M}$ TEP in $100 \mathrm{~mL}$ ethanol and stored at $4{ }^{\circ} \mathrm{C}$. The intermediate working standards were prepared by diluting the MDA stock solution with water to concentrations of $0.5,1.0,2.5,5.0,7.5$ and $15 \mathrm{nmol} / \mathrm{ml}$. The MDA levels in the samples were expressed as $\mathrm{nmol} / \mathrm{ml}$ of serum.

\section{Determination of alanine aminotransferase (ALT) and aspartate aminotransferase (AST) activity}

Commercial ELISA kits from Cusabio (China) were used to determine the serum ALT and AST levels. The serum samples were centrifuged after thawing before the assay was performed. All the reagents were prepared and the assays performed in accordance with the manufacturer's protocol provided with the kit. The optical density was determined using a microplate reader set to $450 \mathrm{~nm}$. The AST and ALT activities were expressed as units per gram of wet tissue.

\section{Statistical analysis}

All presented data are expressed as mean values \pm standard error (SE). One-way analysis of variance (ANOVA) was performed followed by an unpaired student's $t$-test to analyze group differences. Numerical data were correlated with SPSS 16.0 statistical software (Chicago, II, USA). The significance level was set to $p \leq 0.05$, $\mathrm{p} \leq 0.01, \mathrm{p} \leq 0.001$.

\section{RESULTS}

\section{Lead concentration in tissues}

There was no significant difference observed in the $\mathrm{Pb}$ concentration in the analyzed tissues from the negative control group and the group treated with only bromelain $(\mathrm{Br})$. Overall, the effect of bromelain treatment was more marked in the kidneys and spleen. 


\section{Kidneys}

The concentration of $\mathrm{Pb}$ in kidneys was invariably significantly higher $(\mathrm{p} \geq 0.001)$ in rats from the positive control groups ( $\mathrm{Pb} 30$ and $\mathrm{Pb} 60$ ) exposed to lead only, in comparison to the negative control group. Bromelain administration to lead exposed groups $(\mathrm{Pb} 30+\mathrm{Br}$ and $\mathrm{Pb} 60+\mathrm{Br})$ did reduce the $\mathrm{Pb}$ concentration significantly $(\mathrm{p} \geq 0.01)$ in comparison to the positive controls (Pb30 and Pb60) groups (Fig. 1).

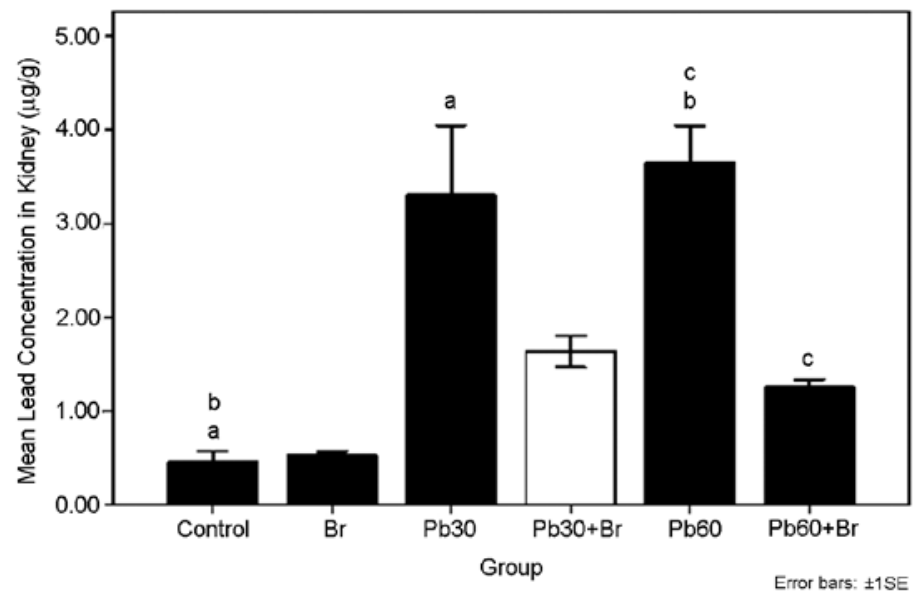

Fig. 1. Effect of stem bromelain treatment on lead concentration in kidney of rats exposed to lead acetate $(\mathrm{PbAc})$. Values are expressed as mean \pm standard error $(\mathrm{n}=4)$. Same letters indicate significant differences between groups ( $p \geq 0.01, p \geq 0.001$ )

\section{Liver}

In the liver, the $\mathrm{Pb}$ concentration was significantly $(\mathrm{p} \geq 0.001)$ higher only in the positive control group with the higher dose of $\mathrm{Pb}(\mathrm{Pb} 60)$ in comparison to the control. The value observed was also significantly $(p \geq 0.05)$ higher than that observed in the group exposed to a lower dose of $\mathrm{Pb}(\mathrm{Pb} 30)$. Although there was a drop in $\mathrm{Pb}$ accumulation in the groups $\mathrm{Pb} 30+\mathrm{Br}$ and $\mathrm{Pb} 60+\mathrm{Br}$ on bromelain treatment, the decrease was not statistically significant in comparison to the positive control groups (Fig. 2).

\section{Spleen}

The concentration of $\mathrm{Pb}$ in spleen was invariably significantly higher $(\mathrm{p} \geq 0.001)$ in rats from the positive control groups ( $\mathrm{Pb} 30$ and $\mathrm{Pb} 60)$ exposed to lead only, in comparison to the negative control group. The treatment with bromelain was equally effective in lowering the $\mathrm{Pb}$ concentration in both $\mathrm{Pb} 30+\mathrm{Br}(\mathrm{p} \geq 0.001)$ and $\mathrm{Pb} 60+\mathrm{Br}$ $(\mathrm{p} \geq 0.01)$ in comparison to the positive control groups (Fig. 3). 


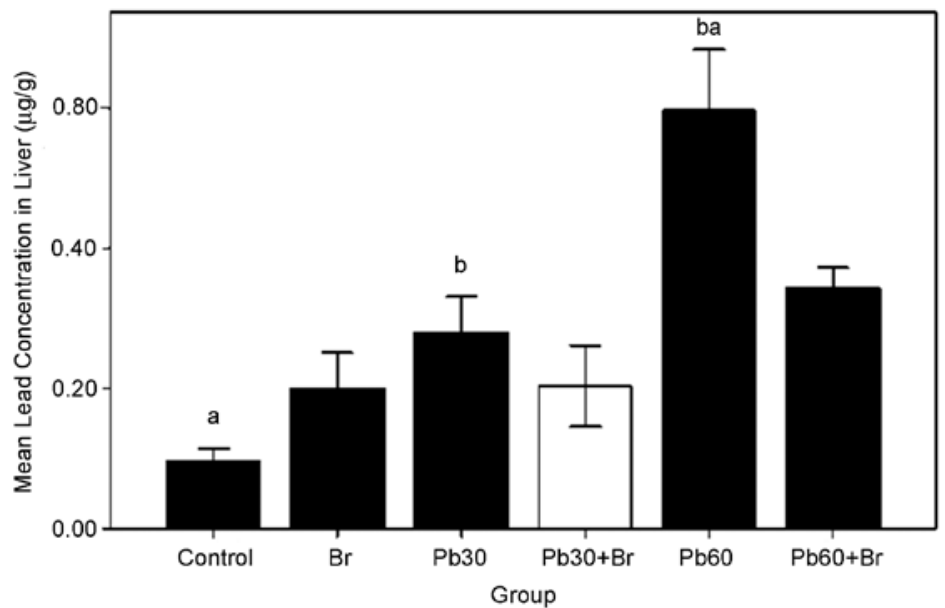

Fig. 2. Effect of stem bromelain treatment on lead concentration in liver of rats exposed to $30 \mathrm{mg} / \mathrm{kg}$ and $60 \mathrm{mg} / \mathrm{kg}$ of lead acetate $(\mathrm{PbAc})$. Values are expressed as mean \pm standard error $(\mathrm{n}=4)$. Same letters indicate significant differences between groups ( $\mathrm{p} \geq 0.05, \mathrm{p} \geq 0.001$ )

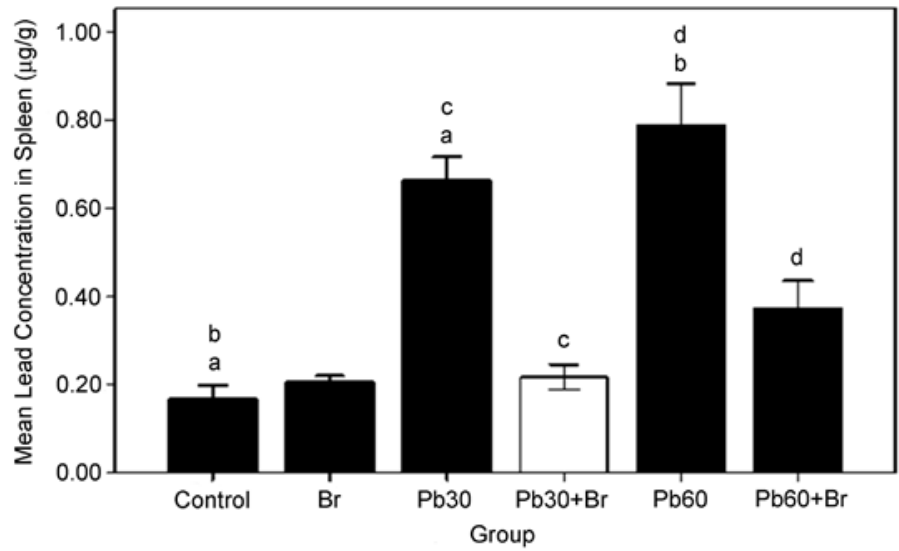

Fig. 3. Effect of stem bromelain treatment on lead concentration in spleen of rats exposed to $30 \mathrm{mg} / \mathrm{kg}$ and $60 \mathrm{mg} / \mathrm{kg}$ of lead acetate $(\mathrm{PbAc})$. Values are expressed as mean \pm standard error $(\mathrm{n}=4)$. Same letters indicate significant differences between groups ( $p \geq 0.01, p \geq 0.001)$

\section{Blood biochemical variables}

\section{Serum MDA levels}

There was no significant difference observed in the serum MDA levels in the negative control group and the group exposed to bromelain alone. Exposure to $\mathrm{Pb}$ significantly $(\mathrm{p} \geq 0.001)$ enhanced the serum MDA levels in both positive control groups 
$(\mathrm{Pb} 30$ and $\mathrm{Pb} 60)$. Within the group exposed to the lower dose of $\mathrm{Pb}(30 \mathrm{mg} / \mathrm{kg}$ body $\mathrm{wt} /$ day), treatment with bromelain significantly $(\mathrm{p} \geq 0.001)$ lowered the serum MDA levels. However, bromelain treatment was not effective whithin the group exposed to the higher dose of $\mathrm{Pb}(60 \mathrm{mg} / \mathrm{kg}$ body wt/day), as there was no significant difference observed in the MDA levels between the groups, $\mathrm{Pb} 60$ and $\mathrm{Pb} 60+\mathrm{Br}$ (Fig. 4).

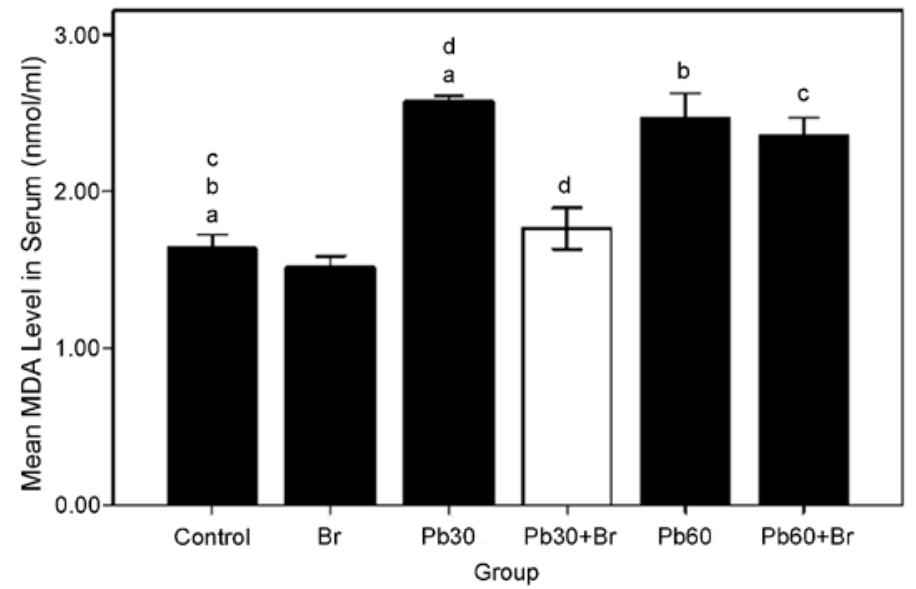

Fig. 4. Effect of stem bromelain treatment serum MDA levels (nmol/ml) of rats exposed to $30 \mathrm{mg} / \mathrm{kg}$ and $60 \mathrm{mg} / \mathrm{kg}$ of lead acetate $(\mathrm{PbAc})$. Values are expressed as mean \pm standard error $(\mathrm{n}=4)$. Same letters indicate significant differences between groups $(\mathrm{p} \geq 0.01, \mathrm{p} \geq 0.001)$

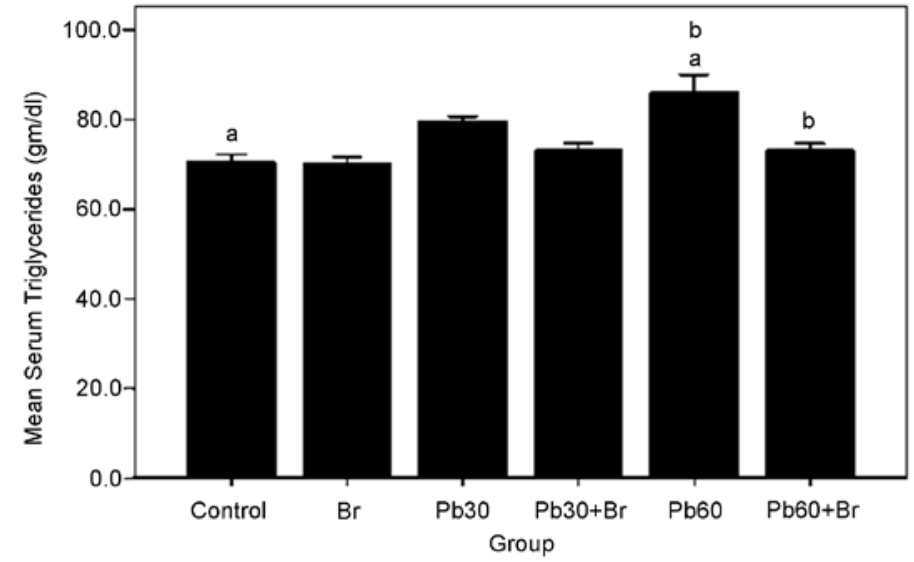

Fig. 5. Effect of stem bromelain treatment serum triglyceride levels ( $\mathrm{gm} / \mathrm{dl}$ ) of rats exposed to $30 \mathrm{mg} / \mathrm{kg}$ and $60 \mathrm{mg} / \mathrm{kg}$ of lead acetate $(\mathrm{PbAc})$. Values are expressed as mean \pm standard error $(\mathrm{n}=4)$. Same letters indicate significant differences between groups ( $\mathrm{p} \geq 0.01, \mathrm{p} \geq 0.001$ ) 


\section{Serum triglycerides and cholesterol}

There was no significant difference observed in the levels of serum triglycerides and cholesterol in the negative control group and the group exposed to bromelain alone $(\mathrm{Br})$. Exposure to $\mathrm{Pb}$ showed a significant $(\mathrm{p} \geq 0.01)$ increase in the serum triglyceride

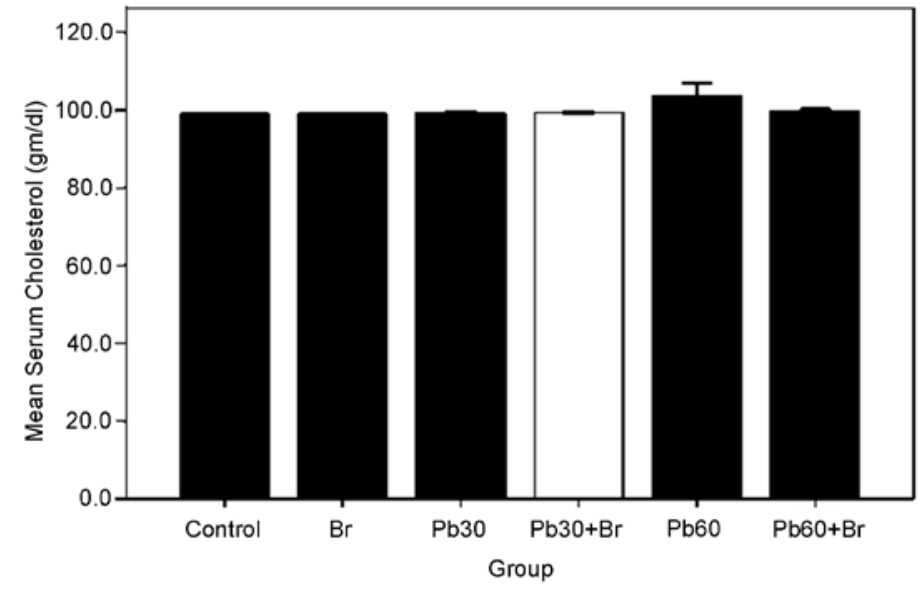

Fig. 6. Effect of stem bromelain treatment serum cholesterol levels (gm/dl) of rats exposed to $30 \mathrm{mg} / \mathrm{kg}$ and $60 \mathrm{mg} / \mathrm{kg}$ of lead acetate $(\mathrm{PbAc})$. Values are expressed as mean \pm standard error $(\mathrm{n}=4)$

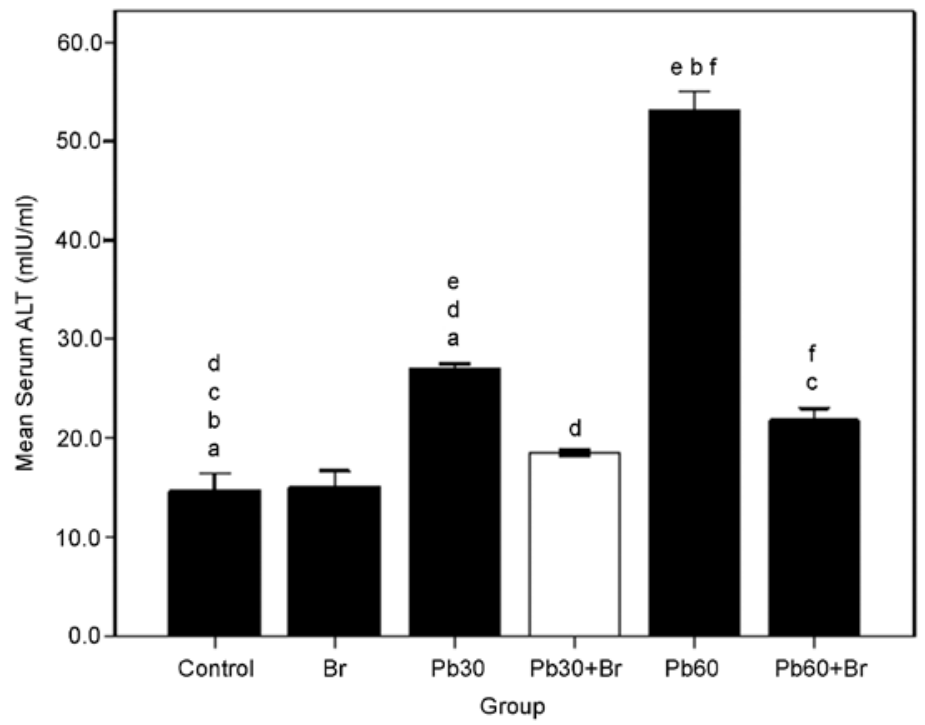

Fig. 7. Effect of stem bromelain treatment serum ALT levels (mlU/ml) of rats exposed to $30 \mathrm{mg} / \mathrm{kg}$ and $60 \mathrm{mg} / \mathrm{kg}$ of lead acetate $(\mathrm{PbAc})$. Values are expressed as mean \pm standard error $(\mathrm{n}=4)$. Same letters indicate significant differences between groups ( $p \geq 0.01, p \geq 0.001$ ) 
level only at the higher dose $(\mathrm{Pb} 60)$ when compared to the negative control. Within the high dose groups $(\mathrm{Pb} 60$ and $\mathrm{Pb} 60+\mathrm{Br})$, treatment with bromelain showed a significant $(\mathrm{p} \geq 0.01)$ reduction in the serum triglycerides level. However, there was no significant effect of $\mathrm{Pb}$ exposure and the bromelain treatment in the groups exposed to the lower dose of $\mathrm{Pb}$ (30 mg/kg body wt/day) (Fig. 5). Further, during the experimental period there was no significant change in the serum cholesterol levels between all experimental groups (Fig. 6).

\section{Serum alanine aminotransferase (ALT) and aspartate aminotransferase(AST)}

There was no significant difference observed in the levels of serum ALT and AST in the negative control group and the group exposed to bromelain alone $(\mathrm{Br})$. In comparison to the negative control group, the groups exposed to $\mathrm{Pb}(\mathrm{Pb} 30$ and $\mathrm{Pb} 60)$ recorded a significant $(\mathrm{p} \geq 0.001)$ increase in the serum ALT levels. The increase in the $\mathrm{Pb}$ exposed groups was dose-dependent being significantly $(\mathrm{p} \geq 0.001)$ higher in group exposed to the higher dose of lead $(\mathrm{Pb} 60)$ in comparison to the group exposed to lower dose of lead $(\mathrm{Pb} 30)$. Treatment with bromelain was effective at both doses of $\mathrm{Pb}$ exposure. A significant $(\mathrm{p} \geq 0.01)$ decrease in the serum ALT level was observed in the group, $\mathrm{Pb} 30+\mathrm{Br}$ in comparison to the $\mathrm{Pb} 30$. Similarly, whithin the high dose groups $(\mathrm{Pb} 60$ and $\mathrm{Pb} 60+\mathrm{Br})$, the bromelain treatment significantly $(\mathrm{p} \geq 0.001)$ reduced the serum ALT levels (Fig. 7). The pattern of the serum AST level was dif-

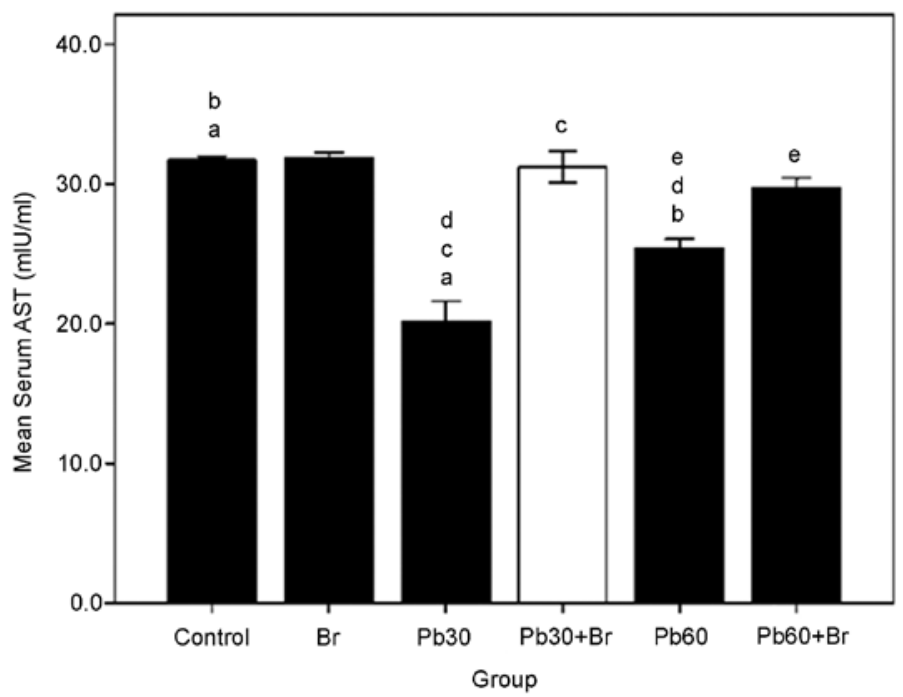

Fig. 8. Effect of stem bromelain treatment serum AST levels $(\mathrm{mlU} / \mathrm{ml})$ of rats exposed to $30 \mathrm{mg} / \mathrm{kg}$ and $60 \mathrm{mg} / \mathrm{kg}$ of lead acetate $(\mathrm{PbAc})$. Values are expressed as mean \pm standard error $(\mathrm{n}=4)$. Same letters indicate significant differences between groups $(\mathrm{p} \geq 0.01, \mathrm{p} \geq 0.001)$ 
ferent, a significant $(\mathrm{p} \geq 0.001)$ decrease was observed in the untreated lead exposed groups $(\mathrm{Pb} 30$ and $\mathrm{Pb} 60)$ in comparison to the control. Treatment with bromelain significantly ( $\mathrm{Pb} 30+\mathrm{Br}, \mathrm{p} \geq 0.001 ; \mathrm{Pb} 60+\mathrm{Br}, \mathrm{p} \geq 0.05)$ enhanced the serum AST levels and restored it to a level comparable to the control (Fig. 8).

\section{DISCUSSION}

Our study did not show any adverse effects of stem bromelain administration on the rats during the experimental period, the parameters assessed, lead accumulation in kidney, liver and spleen, serum MDA levels, ALT and AST activity, cholesterol and triglycerides in group administered only bromelain were comparable to the control. Lead exposure at both doses $(30 \mathrm{mg} / \mathrm{kg}$ and $60 \mathrm{mg} / \mathrm{kg})$ in the rats did increase the accumulation of lead in the analyzed tissues being more marked in the kidney as reported earlier [13] followed by spleen and liver. The treatment with bromelain did cause a significant reduction of $\mathrm{Pb}$ accumulation in the kidney and spleen, however, in the liver there was no detectable change observed due to bromelain treatment. The levels of serum MDA, a biomarker of metal-induced lipid peroxidation, were significantly increased in the groups exposed to both low and high doses of $\mathrm{Pb}$ in comparison to the control group which are consistent with the earlier studies [15, 16]. Bromelain effectively reduced the MDA levels in the group exposed to a lower dose of lead. Our results on lead bioaccumulation and lipid peroxidation demonstrate a moderate ameliorative effect of stem bromelain on lead-induced toxicity in the rats. This can be explained on the presence of cysteine, an amino acid with known antioxidant properties. It is also an important precursor in the production of antioxidant glutathione, which protects cells from toxins such as free radicals incriminated in lead-induced oxidative stress [19]. Thus the cysteine in the bromelain could be a factor which helped in combating the oxidative stress. Chelation therapy has historically been used in attempts to reduce the body burden of toxic metals, including lead in highly symptomatic patients with elevated biological markers [5]. The majority of proteins and peptides that function in the uptake, distribution, storage or detoxification of essential and non-essential metal ions possess one or several metal-binding sites. The Cys-X-X-Cys- and -Cys-Cys- motifs of various proteins are well known for their heavy metal binding properties [8]. It has long been acknowledged that sulfhydryl-containing compounds have the ability to chelate metals. The sulfur-containing amino acids methionine and cysteine, tripeptide glutathione which also contains cysteine all contribute to the chelation and excretion of metals from the human body. The presence of a highly reactive cysteine in bromelain could have a plausible chelating effect. Further, our findings on lipid profile and biochemical parameters indicative of liver functions reveal a modulatory effect of lead exposure to the rats which was restored by the bromelain treatment. Several studies have incriminated lead exposure to lipid abnormalities and risk of atherosclerosis [17]. However, effect of $\mathrm{Pb}$ exposure on the lipid profile has variable effects as evident from previous reports [3]. In line 
with this, the results of our study demonstrated no significant effect of $\mathrm{Pb}$ exposure (both at low and high dose) on the serum cholesterol levels of the rats during the experimental period and was comparable to the control. Further, the serum triglyceride levels did not show either significant change in the groups exposed to low dose of $\mathrm{Pb}$. Only the group exposed to the higher dose of lead $(60 \mathrm{mg} / \mathrm{kg})$ showed an elevated level of triglycerides and treatment with bromelain significantly reduced the levels in the serum. Similar to our results, no significant change in the serum cholesterol and triglycerides levels were reported in a study on long term exposure to $\mathrm{Pb}$ in albino rats [3]. Dyslipidemia is defined as elevated total cholesterol or triglycerides [23], thus the $\mathrm{Pb}$-induced dyslipidemia observed at the higher dose of exposure was alleviated by the bromelain treatment which could be attributed to its anti-inflammatory nature. Liver enzymes such as ALT and AST are marker enzymes for liver function and integrity [1]. These enzymes are usually elevated in acute hepatotoxicity or mild hepato-cellular injury, but also tend to decrease with prolonged intoxication due to liver damage [9]. In consensus with previous studies [15, 21], in the present study the serum ALT levels were increased by $\mathrm{Pb}$ exposure in a dose dependent manner in comparison to the control. And at both levels of lead exposure $(30 \mathrm{mg} / \mathrm{kg}$ and 60 $\mathrm{mg} / \mathrm{kg}$ ) the bromelain significantly reduced the serum ALT levels. Our findings are supported with the findings of a dose-response study by Bahde et al. [4] on the evaluation of immunomodulatory action of the protease bromelain for the treatment of hepatic ischemia/reperfusion (I/R) injury. It was reported that, after $I / R$, rats treated with $0.1 \mathrm{mg} / \mathrm{kg}$ b.w. bromelain showed an improved microcirculation, reduction in leukocyte adhesion, apoptosis rates, Kupffer cell activation and endothelial cell damage and significantly lower AST levels compared with untreated animals [4].

Based on a broad assessment of all the end points investigated in the present study bromelain proved to be effective in alleviating the lead-induced toxicity though the effect of bromelain was also not preferential over a particular dose of $\mathrm{Pb}$. The use of natural antioxidants along or in conjunction with chelation therapy has not been extensively investigated yet. Bromelain known for its therapeutic potential is a widely used and recommended dietary supplement and its use could prove to be a potential novel strategy to treat pathological and toxicological consequences of oxidative stress in conjugation with other antioxidants or chelators. Thus we recommend the potential use of bromelain as a phytotherapeutic agent in metal intoxication and a host of human diseases including metabolic disorders.

\section{ACKNOWLEDGEMENT}

This research project was supported by a grant from the "Research Center of the Female Scientific and Medical Colleges", Deanship of Scientific Research, King Saud University, Riyadh, Saudi Arabia. 


\section{REFERENCES}

1. Adaramoye, O. A., Osaimoje, D. O., Akinsanya, A. M., Nneji, C. M., Fafunso, M. A., Ademowo, O. G. (2008) Changes in antioxidant status and biochemical indices after acute administration of artemether, artemether-lumefantrine and halofantrine in rats. Basic Clin. Pharmacol. Toxicol. 102, $412-418$.

2. Ahamed, M., Siddiqui, M. K. J. (2007) Low level lead exposure and oxidative stress: current opinions. Clin. Chim. Acta 383, 57-64.

3. Allouche, L., Hamadouche, M., Touabti, A., Khennouf, S. (2011) Effect of long-term exposure to low or moderate lead concentrations on growth, lipid profile and liver function in albino rats. Adv. Biol. Res. 5, 339-347.

4. Bahde, R., Palmes, D., Minin, E., Stratmann, U., Diller, R., Haier, J., Spiegel, H. U. (2007) Bromelain ameliorates hepatic microcirculation after warm ischemia. J. Surg. Res. 139, 88-96.

5. Baum, C. R. (1999) Treatment of mercury intoxication. Curr. Opin. Pediatr. 11, 265-268.

6. Beyer, W. N., Gaston, G., Brazzle, R., O’Connell, A. F., Audet, D. J. (2007) Deer exposed to exceptionally high concentrations of lead near the Continental Mine in Idaho, SA. Environ. Toxicol. Chem. 26, 1040-1046.

7. Chobotova, K., Vernallis, A. B., Majid, F. A. A. (2010) Bromelain's activity and potential as an anticancer agent: current evidence and perspectives. Cancer Lett. 290, 148-156.

8. Cobbett, C., Goldsbrough, P. (2002) Phytochelatins and metallothionein: roles in heavy metal detoxification and homeostasis. Annu. Rev. Plant Physiol. 53, 159-182.

9. Cornelius, C. E. (1979) Biochemical evaluation of hepatic function in dogs. JAAHA 15, 259-269.

10. Dash, D. K., Yeligar, V. C., Nayak, S. S., Ghosh, T., Rajalingam, R., Sengupta, P., Maiti, B. C., Maity, T. K. (2007) Evaluation of hepatoprotective and antioxidant activity of Ichnocarpus frutescens (Linn.) R. Br. on paracetamol-induced hepatotoxicity in rats. Trop. J. Pharm. Res. 6, 755-765.

11. Gregory, S., Kelly, N. D. (1996) Bromelain: A literature review and discussion of its therapeutic applications. Alt. Med. Rev. 4, 243-257.

12. Gürer, H., Özgünes, H., Saygin, E., Ercal, N. (2001) Antioxidant effect of taurine against lead-induced oxidative stress. Arch. Environ. Contam. Toxicol. 41, 397-402.

13. Humphreys, D. J. (1991) Effects of exposure to excessive quantities of lead on animals. Brit. Vet. J. 147, 18-30

14. Koivula, M. J., Eeva, T. (2010) Metal-related oxidative stress in birds. Environ. Pollut. 158, 23592370.

15. Lakshmi, B. V. S., Sudhakar, M., Aparna, M. (2013) Protective potential of Black grapes against lead induced oxidative stress in rats. Environ. Toxicol. Pharmacol. 35, 361-368.

16. Mohammad, I. K., Mahdi, A. A., Raviraja, A., Najmul, I., Iqbal, A., Thuppil, V. (2008) Oxidative stress in painters exposed to low lead levels. Arh. Hig. Rada Toksikol. 59, 161-169.

17. Newairy, A. S. A., Abdou, H. M. (2009) Protective role of flax lignans against lead acetate induced oxidative damage and hyperlipidemia in rats. Food Chem. Toxicol. 47, 813-818.

18. Pavan, R., Jain, S., Kumar, A. (2012) Properties and therapeutic application of bromelain: a review. Biotechnol. Res. Int. 2012, 976203, doi: 10.1155/2012/976203.

19. Piste, P. (2013) CYSTEINE-Master Antioxidant. Int. J. Pharmaceut. Chem. Bio. Sci. 3, 143-149.

20. Reglero, M. M., Taggart, M. A., Castellanos, P., Mateo, R. (2009) Reduced sperm quality in relation to oxidative stress in red deer from a lead mining area. Environ. Pollut. 157, 2209-2215.

21. Sharma, A., Sharma, V., Kansal, L. (2009) Therapeutic effects of Allium sativum on lead-induced biochemical changes in soft tissues of Swiss albino mice. Pharmacogn. Mag. 5, 364-371.

22. Taussig, S. J., Batkin, S. (1988) Bromelain, the enzyme complex of pineapple (Ananas comosus) and its clinical application. An update. J. Ethnopharmacol. 22, 191-203.

23. Wells, B. G., Dipiro, J. T., Schwinghammer, T. L., Cecily, V., Dipiro, C. V. (2009) Pharmacotherapy Handbook. Seventh Edition. McGraw-Hill, New York.

24. Xia, D., Yu, X., Liao, S., Shao, Q., Mou, H., Ma, W. (2010) Protective effect of Smilax glabra extract against lead-induced oxidative stress in rats. J. Ethnopharmacol. 130, 414-420. 